\author{
Review Article
}

\title{
CRITICAL REVIEW ON KAIDARYADI KASHAYA IN IRRITABLE BOWEL SYNDROME W.S.R TO GRAHANI
}

\section{Aswathy $\mathbf{M}^{1 *}$, Jithesh $\mathbf{M}^{2}$}

*1 PhD Scholar, ${ }^{2}$ Professor \& HOD, Department of Kayachikitsa, V.P.S.V Ayurveda College, Kottakkal, Kerala, India.

\begin{tabular}{l} 
Article info \\
\hline Article History: \\
Received: 24-08-2021 \\
Revised : 01-09-2021 \\
Accepted: 23-09-2021 \\
Published: 16-10-2021 \\
\hline KEYWORDS: \\
Kaidaryadi \\
kashaya, IBS, \\
Tridoshahara, \\
Pachana \\
deepana, Kleda \\
soshana, Grahani.
\end{tabular}

ABSTRACT
Irritable Bowel Syndrome (IBS) is a functional gastrointestinal disorder characterized by
varying bowel habits and recurrent abdominal pain. An observational study conducted on
25 patients of IBS who attended the Kayachikitsa O.P.D, V.P.S.V Ayurveda college, Kottakkal
noticed Muhurbadha muhurdrava varchas (Increased frequency of loose stools after meals)-
$88 \%$, Saruja malapravrithi (abdominal pain during defaecation)- $60 \%$, Daha (burning
sensation)- $60 \%$ and Sleshmasamsrishta mala (mucus in stools)- 52\% as the common
presentations. On assessing the symptoms, Grahani dushti, Agnimandya, Arsas and Tridosha
involvement can be found predominating in the pathophysiology. Kaidaryadi kashayam is a
well known traditional decoction formulation from the text Chikitsa manjari- Mahodara
chikitsa. This yoga having Tridoshahara, Kleda soshana, Pachana deepana, Vatanulomana
and Grahani balya property is found to be effective in reducing the symptoms of IBS, when
administered along with suitable formulations. Kaidaryadi kashayam contain 4 drugs i.e.,
Zingiber officinale, Murraya koeinigii, Terminalia chebula and Tricosanthes dioica. The action
of Kaidaryadi kashayam is evaluated for its action on IBS based on available clinical and
research data here in this paper. The ingredients inhibits proton pump, thereby reducing
the gastric secretion, helps in the protection of gastric mucosa, reduces the acidity of gastric
juice and acts as a strong cytoprotective. So based on the available data we can say
Kaidaryadi kashayam is an effective formulation in the management of Lower GIT
pathology of IBS.

\section{INTRODUCTION}

Irritable Bowel Syndrome (IBS) is a gastrointestinal disorder characterized by altered bowel habits and abdominal pain/discomfort in the absence of detectable structural abnormalities.[1] IBS patients are having impaired quality of life. The prevalence of IBS varies across the world, from as high as $10 \%-20 \%$ in the West, to as low as $4.2 \%$ in India. ${ }^{2]}$ The majority of diseases affecting public now are because of these new age lifestyles, habits, mental stress, occupational and environmental factors. IBS is one among them and published studies conclude that almost $88 \%$ of IBS patients are having some sort of psychological disturbances.

\section{Access this article online}

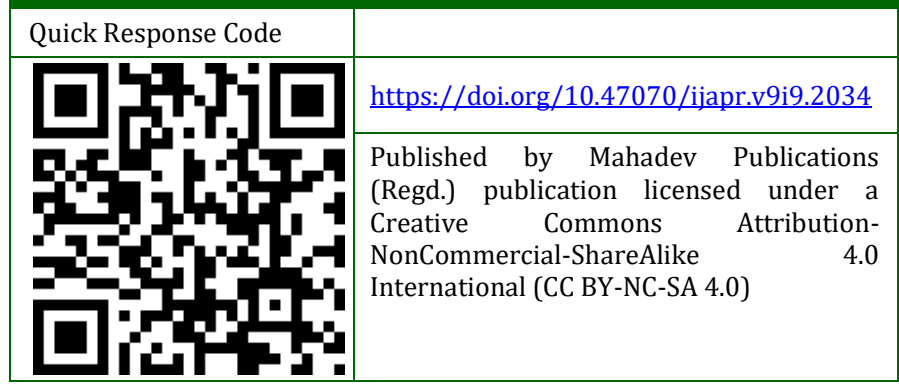

In Ayurveda, IBS can be explained through the light of Grahani due to similarity in the pathology as well as clinical presentation. Grahani, the Pittadhara $\mathrm{kala}^{[3]}$ as mentioned by the Acharyas is vitiated due to Nidanas causing Agnimandhya and the digestion is not occurring properly or after partial digestion, the food is eliminated as faeces. The holding capacity of the organ of Grahani is deranged here.

An observational study was conducted in 25 IBS attended the OPD of the institution to observe the common presentations and to sort out the etiological factors contributing to the condition. It was observed that the Nidanas- Akala bhojana, Vishamasana, Katu Rasa Atyupayoga and Manasasadana were more frequent among the observed. In the premonitory symptoms- Anaha, Adhmana and Antrakoojana were the most seen. While noting the Rupas or clinical features- Muhurbadha muhurdrava varchas, Saruja malapravrithi and Sleshmayukta mala were the most complained ones. 
More than $50 \%$ of the cases have Arsas as the associated illness. Considering all these features, a yoga having Tridoshahara, Kleda Soshana, Deepana Pachana, Vatanulomana and Grahanibalya was selected here for the management. Thus the Kaidaryadi Kashaya from Chikitsa Manjari Mahodara Chikitsa[4] was taken as the drug of choice in the presentation of Grahani where lower GIT is involved the most of the cases.

\section{Samprapthi Ghatakas of Grahani}

- Dosha: Vatapradhana Tridosha (Kledaka Kapha, Pachaka Pitta, Samana - Apana- Vyana Vayu)

(Vata- Punapuna srijet varchas, Drava Varchas, Saruja Malapravrithi

Pitta- Drava Varchas, Daha in Udara, Payu

Kapha- SleshmaYukta Mala, Krite Api Akritha Samjnatha, Tantuvat Mala Pravrithi)[5]

- Dushya: Rasa

- Mala: Pureesha

- Srothas: Pureeshavaha Srothas (Atisrishta atibadha varchas, Sasabda soola Mala pravrithi)

Rasavaha Srothas (Aruchi, Asyavairasya, Agnimandya)

Annavaha Srothas (Anannabhilasha, Arochaka, Chardi)[6]

- Srotodushti: Sanga, Vimargagamana, Atipravritti

- Agni: Mandagni/Vishamagni

- Rogamarga: Abhyanthara (Mahasrothas)[7]

\section{Samprapthi}

The important factors which play a significant role in most of the digestive disorder are malfunctioning of Agni and Vata Dosha along with significant contribution of mind in the physiological function of digestive system. Grahani is known as the seat of Agni and the strength of Agni in Grahani is known to hold the food for the appropriate duration for the optimum digestion. It is situated anatomically between Amashaya and Pakvashaya, often referred as Pacayamanashaya. Sushruta refers Pitta dhara kala, the sixth Kala as Grahani and it helps in the Shoshana and Pachana of four types of food. Grahani holds the Apakva Anna for adequate time for digestion and releases the Pakvaanna after proper digestion. When Agni is weakened, food is not digested properly and it is expelled out through upper (mouth) and lower outlets (anus) of the body. The improperly digested food when expelled out through anus in Pakva or Apakva state, the condition is known as Grahani. In Samhita, the term Grahani refers to both the anatomical site which is responsible for holding the food for proper digestion and the disease in which the digestion of the food is affected and undigested food is expelled out. The symptoms Malaprvritti, abdominal pain (Udarsoola), stool with mucus (Apakvamala pravritti), anorexia (Aruchi), heaviness in abdomen (Udaragourava), fatigue (Alasya), and indigestion (Ajeerna) resemble with the Grahani Roga.

Samprapthi of Grahani can be well thought-out in two ways- affecting the upper GIT or involving the lower GIT. In the first one, the Aharaja, Viharaja and Manasika nidanas are causing Pachaka pitta and Samanavayu dushti which in turn leads to Agnimandhya, Ama and Grahani dushti producing the features. ${ }^{[8]}$ In the other condition involving the lower GIT, Apana vaigunya, Arsas and Udavartha is having a crucial role. This in sequence leads to Samana vayukopa, Kledaka kaphavridhi and vitiate the Grahani producing the clinical features Muhurbadha muhurdrava varchas, Sleshma Yukta Mala, Krite Api Akritha Samjnatha, Tantuvat Mala Pravrithi etc. In the condition involving lower GIT, Kaidaryadi kashya is established to be very much effective when administered along with other apt combinations.

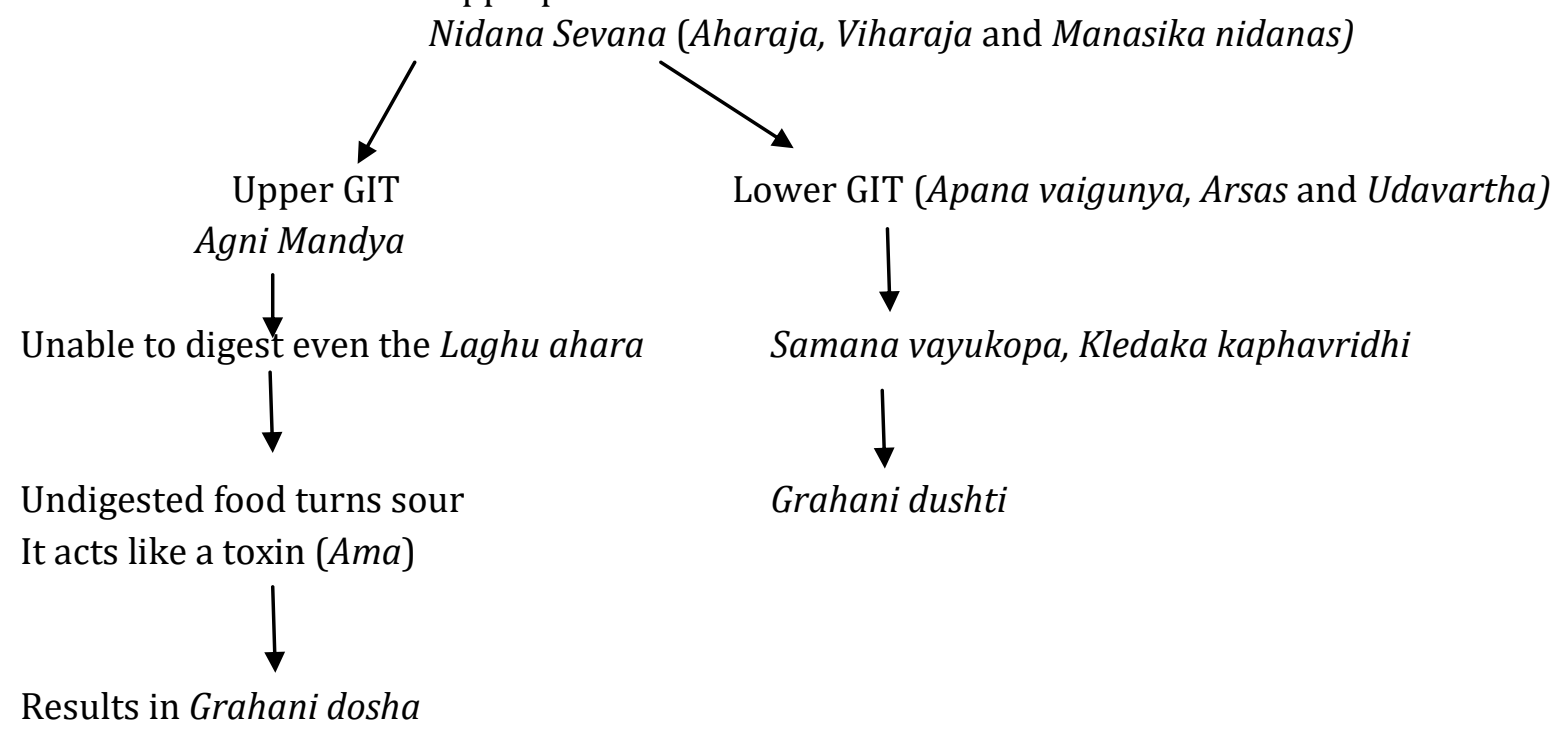


It is very difficult to attribute the diagnosis of Grahani in Purvarupa avastha. In Purva rupa avastha, the symptoms manifested need not point towards Grahani dushti and they may be manifestation of primary Agni dushti and depending on the change in Nidana Sevana it can take any course of Samprapti such as Atisara, Gulma, Udara etc. Hence to have an affirmative diagnosis of Grahani, above mentioned cardinal features must be present in Vyakta rupa avastha.

\section{Kaidaryadi Kashaya}

Chukkonnu moonu kariveppu patola pathye

Nannalu kolka pulare jadareshu kashaya yoge

Induppu tippalikal menpodi kolka pakshe

Ravenkil unnuvatinanpodu munpil venduu. (Chi. Manjari)

The four ingredients - Sunti (1 part), Kaidarya (3 parts), Patola and Hareetaki (4 parts) are mentioned in the yoga along with Saindhava and Pippali as Prakshepa dravyas and the time of administration is mentioned as morning and evening before food.

\section{Ingredients (1:3:4:4)}

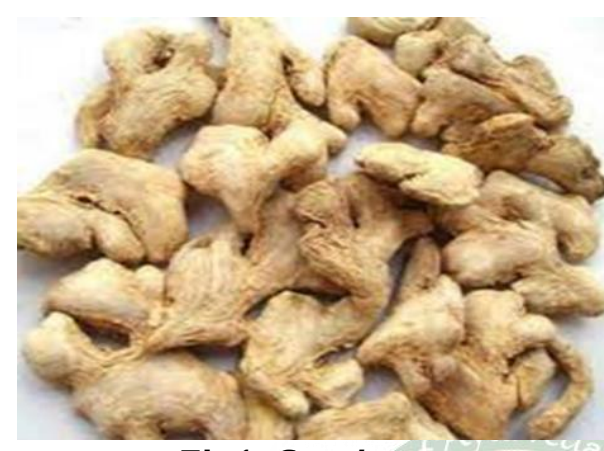

Fig1: Sunti

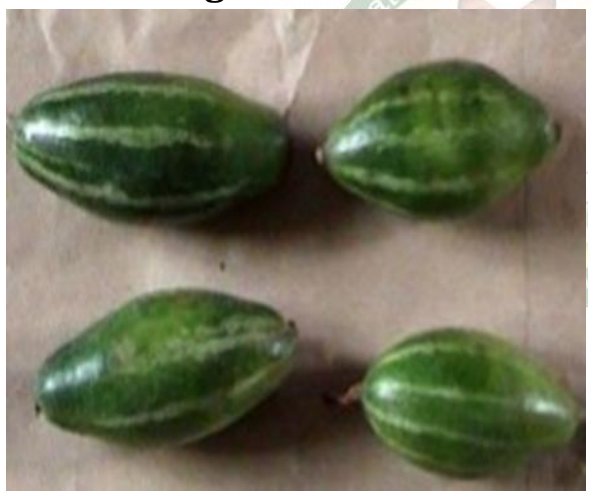

Fig 3: Patola

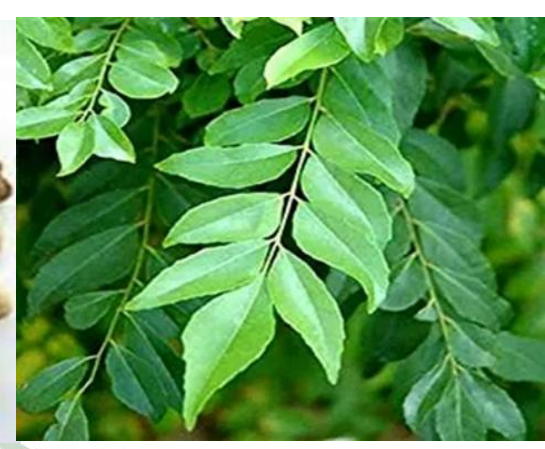

Fig: 2 - Kaidarya

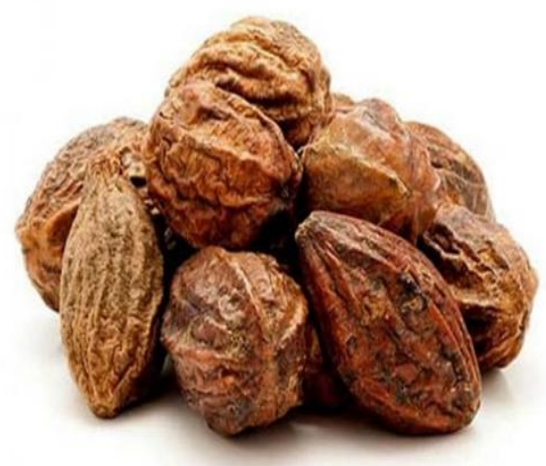

Fig 4 : Pathya

Table 1: Mode of Action In Ayurveda - Rasa Panchaka[9]

\begin{tabular}{|l|l|l|l|l|l|}
\hline Drug & Rasa & Guna & Veerya & Vipaka & Karma \\
\hline $\begin{array}{l}\text { 1.Sunti } \\
\text { (Zingiber officinalis- } \\
\text { Zingiberaceae) }\end{array}$ & Katu & $\begin{array}{l}\text { Guru } \\
\text { Ruksha } \\
\text { Teekshna }\end{array}$ & Usna & Katu & $\begin{array}{l}\text { Vatakaphahara } \\
\text { Deepana } \\
\text { Pachana }\end{array}$ \\
\hline $\begin{array}{l}\text { 2. Kaidarya } \\
\text { (Murraya koenigi- } \\
\text { Rutaceae) }\end{array}$ & $\begin{array}{l}\text { Katu } \\
\text { Tikta } \\
\text { Kashaya }\end{array}$ & $\begin{array}{l}\text { Laghu } \\
\text { Ruksha }\end{array}$ & Seeta & Katu & $\begin{array}{l}\text { Kaphapitta hara } \\
\text { Krimighna }\end{array}$ \\
\hline $\begin{array}{l}\text { 3. Patola } \\
\text { (Trichosanthes dioica - } \\
\text { Cucurbitaceae) }\end{array}$ & $\begin{array}{l}\text { Tikta } \\
\text { Katu }\end{array}$ & $\begin{array}{l}\text { Laghu } \\
\text { Ruksha }\end{array}$ & Usna & Katu & Bhedana \\
\hline
\end{tabular}




\begin{tabular}{|c|c|c|c|c|c|}
\hline & & & & & Amlapittahara \\
\hline $\begin{array}{l}\text { 4. Hareetaki } \\
\text { (Terminalia chebula- } \\
\text { Combretaceae) }\end{array}$ & $\begin{array}{l}\text { Pancharasa } \\
\text { (Lavana } \\
\text { varjitha) }\end{array}$ & $\begin{array}{l}\text { Laghu } \\
\text { Ruksha }\end{array}$ & Usna & Madhura & $\begin{array}{l}\text { Tridoshahara } \\
\text { Anulomana } \\
\text { Rasayana } \\
\text { Krimi, Sophahara }\end{array}$ \\
\hline
\end{tabular}

\section{Action of Kaidaryadi Kashaya}

- Rasa-Katu Tikta Kashaya

- Guna- Laghu Ruksha

- Veerya-Usna

- Vipaka-Katu

- Dosha karma: Tridoshahara, Kleda Soshana, Vatanulomana, Kapha Pittahara

- Agni karma: Deepana Pachana

- Srotho karma: Srotosodhana, Lekhana

- Krimighna, Udarahara, Sophahara

Table 2: Mode Of Action - Modern [10]

\begin{tabular}{|c|c|c|}
\hline Drug & Chemical Constituents & Action \\
\hline 1. Sunti & $\begin{array}{l}\text { Gingerols } \\
\text { Zingerons }\end{array}$ & $\begin{array}{l}\text { Proton Pump Inhibitors } \\
\text { Anti Oxidants } \\
\text { Against H. Pylori } \\
\text { Prevents Stress-induced Gastric Damage }\end{array}$ \\
\hline 2. Kaidarya & $\begin{array}{l}\text { Carbazole } \\
\text { Alkaloids }\end{array}$ & $\begin{array}{l}\text { Cytoprotective } \\
\text { Antimicrobial } \\
\text { Reduces Acidity }\end{array}$ \\
\hline 3. Hareetaki & Chebulinic acid & $\begin{array}{l}\text { Proton Pump Inhibitors } \\
\text { Anti -Secretory }\end{array}$ \\
\hline 4. Patola & $\begin{array}{l}\text { Saponins } \\
\text { Tanins }\end{array}$ & $\begin{array}{l}\text { Reduce Pepsin } \\
\text { Cytoprotective }\end{array}$ \\
\hline
\end{tabular}

Zingiber officinale contain active ingredients like gingerols and zingerons are inhibiting proton pump and thereby reducing the gastric secretion. They act as anti oxidants helps in the protection of gastric mucosa. Also acts against H.pylori and other organisms. Murraya koenigii contain carbazole alkaloids which act by cytoprotective and anti microbial properties. It also reduces the acidity of gastric juice. Terminalia chebula contain chebulinic acid which is a known anti secretory agent by inhibiting the proton pump. It also acts against H.pylori and reduces the total acidity of the gastric juice. Tricosanthes dioica contain saponins and tannins which reduce pepsin, and acts as a strong cytoprotective factor. It can be applied to conditions like diarrhea, peptic ulcer; abdominal pain, indigestion etc. Kaidaryadi kashayam is an effective formulation against peptic ulcers. It acts as Deepana and Pachana, Tridoshahara, Vatanulomaka and Malanulomaka. So it relieves in the symptom of Muhur Mala Pravritti in Grahani Roga.

Matra (Dose): 2 Pala[11] The dose of Kashaya kalpana is mentioned as two Palas and the patients are being advised to have $15 \mathrm{ml}$ of Kashaya with $45 \mathrm{ml}$ lukewarm water twice daily which signifies the 2 Pala. But especially in Gastrointestinal diseases, it is better to advice the patients to prepare Kashaya themselves by collecting the raw drugs from the market to stay away from the usage of preservatives. As the Kaidaryadi kashaya is only having 4 ingredients which are easily available and cost effective, it can be prepared either by crushing or as powder boiling in 16 times water and reducing it to $1 / 8$.

\section{Oushadha Kala (Time of Administration) ${ }^{[12]}$}

To be taken morning and evening before food. Apanavaigunya is taken to consideration here and 'Annadou vigune apane' is the concept. 


\section{Prakshepa}

Saindhava and Pippali Both are Kleda Soshana and Vata Kaphahara which enhances the effect of the Yoga.[13]

\section{Sahapana}

Various combinations can be administered along with the Kashaya, considering the associated Doshas and presentations. A few effective uses in clinical practice are explained below.

Vata- Dhanwantharam gulika, Kankayanam gulika (Arsas)

Pitta-Sudarsanam Churnam

Kapha Pitta-Charngeryadi Gulika, Avipathy Churnam, Kutajatwagadi Lehyam.

KaphaVata- Patadi Gulika, Dadimashtaka Churna, Hutabhugadi Churna.

Infections- Septilin Tab

Sula-Parooshakadi Lehyam

Stress, Insomnia- Manasamitavatakam, Sankhapushpi Churnam.

\section{Phalasruthi (Therapeutic uses Beyond the Books)}

The practical knowledge shared by experienced physician is much more informative than those attained from books. Little information is given below:

1. In lower GIT involved presentation having Arsas and Udavarta Samprapthi, the yoga is found to be very much effective with suitable combinations.

2. Kledasoshana property of the drugs shows its better role in features of Kaphaja Grahani.

3. Observed effective in Crohns disease, UC

4. Due to Yakrit prasadana, Kaphamedohara property found effective in Amoebic liver abscess, fatty liver, liver cirrhosis.

5. In Cholelithiasis, Appendicitis- Kaidaryadi Kashaya + Hinguvachadi Churna + Chavikasava shown better results when administered for 2 weeks.

6. Infections and inflammations in GIT- This yoga can be administered along with septilin tab, Sudarsanam churna.

7. In hyperglycemia, results observed when given along with Arogyavardhini vati.

\section{Samaana Yogas (Similar Formulations)}

\section{Kaidaryapatradi Kashaya[14]}

Kaidaryapatra bhoonimbha karavira sarapunghai sringivera chaturbhaga sahithairva kanaanvitha:

The yoga is mentioned in Arogyakalpadruma Atisara chikitsa and the ingredients are more Deepana Pachana than kaidaryadi kashaya but not much kleda soshana.

2. Kalasakadi Kashayam [15]- Mentioned in Chikitsa Manjari Vishuchika chikitsa and is Soola prasamana and more effective in upper GIT conditions. Only
Patola is missing from Kaidaryadi kashaya and so less Pitta samana.

Kalasaka vijaya mahoushadhai

Sadhitham rasayugakshi bhagasa

Varivarayathi soola trit barman

Veginim api vishuchikam kshanat

\section{Kaidaryadi Gulika[16]}

Kaidarya deepyakamboda samangativishasama

Pishta deepyaka nishkvathe grahani dosha nasana:

Mentioned in Arogyakalpadruma Grahani chikitsa and is Sthambana.

\section{CONCLUSION}

Kaidaryadi kashaya is having Kleda soshana, Tridoshahara, Vatanulomana, Lekhana and Grahani balya properties and is very much effective in Grahani mainly affecting the lower GIT. Due to Sophahara, Kaphamedohara and Yakrit prasadana properties it is found to be very much effective in fatty liver, amoebic liver abscess, IBD etc. As no specific therapeutic indication is given in the yoga, we can infer the wide range of action of this yoga and researches have to be done in this area to explore the same.

\section{ACKNOWLEDGEMENT}

I express my sincere gratitude to Dr.Kiratamoorthy, HOD Samhitha Sidhantha and Dr. Gopikrishna S, Associate Professor, Agadatantra VPSV AVC Kottakkal, for sharing their clinical experiences on this yoga. The authors express sincere thanks to Vaidya Prof. K. S. Dheeman, Director General, CCRAS, Dr. N. Srikanth, Deputy Director General, CCRAS and Dr. C.V Jayadevan, Principal, V.P.S.V Ayurveda College, Kottakkal for their extensive support.

\section{REFERENCES}

1. Fauci AS, Hauser SL, Kasper DL, Longo DL, Jameson JL. Harrison's Principles of Internal Medicines. Vol. II. 18th International Edition. McGraw Hill, New Delhi, Medical Publishing Division: 2002. p. 1971.

2. Nirmal Hanmant, Management of IBS through Ayurveda- A case study, IJAPR June 2019 vol 7 issue 6 pg 40-44

3. Acharya YT, editor. Sushrutha Samhita of Sushruta, Sareerasthana, $2^{\text {nd }}$ ed. Chaukhambha Sanskrit Sansthan; Varanasi: 2004. 5/17.

4. D Sreeman Nambootiri, Chikitsa Manjari Vol I \& II Maahodara chikitsa, $7^{\text {th }}$ edition Vidyarambha publications, 2005, pg-280

5. R K Bhagwan Dash, Charaka Samhitha Chikitsasthana, Vol 4, edition reprint, Choukambha publication, Varanasi, 2004, 15/67-70

6. P S Byadgi, Ayurvediya Vikrithi Vijnan and Roga Vijnan, Vol I, $1^{\text {st }}$ edition, Choukambha publication, 2007, pg 78-118 
7. K R Sreekanta Murthy, Ashtanga Hridaya, Sutra sthana, Vol I, reprint, chowkambha krishnadas academy, Varanasi, 2004, 12/46, pg 175

8. R K Bhagwan Dash, Charaka Samhitha Chikitsa sthana, Vol 4, edition reprint, Choukambha publication, 2004, 15/56-60, pg 29

9. JLN Sastry, Dravya Guna Vijnana- vol II, $2^{\text {nd }}$ edition, chaukambha publishers, varanasi, 2005 pg-209, 250, 519

10. Preethimohan, Review on antiulcerogenic property of Kaidaryadi kashaya- a traditional formulation, IJSAR 2 (9) 2015 pg1-7

11. P Himasagara Chandra murthy, Sarngadara Samhitha, $1^{\text {st }}$ edition, Chowkambha sankrit series, Varanasi, 2001 chapter 2, pg 111
12. K R Sreekanta Murthy, Ashtanga Hridaya, Sutra sthana, Vol I, reprint chowkambha krishnadas academy, Varanasi, 2004, 13/38-41, pg 124

13. JLN SASTRY, Dravya Guna Vijnana- vol II, $2^{\text {nd }}$ edition, chaukambha publishers, varanasi, 2005, pg-452

14. Kaikulangara Ramavarier, Arogyakalpadrumam, Atisarachikitsa, Sahithi books, pg 77

15. D Sreeman Nambootiri, Chikitsa Manjari Vischuchika chikitsa, Vol I \& II, $7^{\text {th }}$ edition, Vidyarambha publications, 2005 November, pg207

16. Kaikulangara Ramavarier, Arogyakalpadrumam, Atisarachikitsa, Sahithi books, pg 80

\section{Cite this article as:}

Aswathy M, Jithesh M. Critical Review on Kaidaryadi Kashaya in Irritable Bowel Syndrome w.s.r to Grahani. International Journal of Ayurveda and Pharma Research. 2021;9(9):45-50.

https://doi.org/10.47070/ijapr.v9i9.2034

Source of support: Nil, Conflict of interest: None Declared
*Address for correspondence Dr. Aswathy M

PhD Scholar,

Department of Kayachikitsa,

V.P.S.V. Ayurveda College,

Kottakkal, Kerala, India.

Email:

draswathym.212@gmail.com

Mobile: 8281630672

Disclaimer: IJAPR is solely owned by Mahadev Publications - dedicated to publish quality research, while every effort has been taken to verify the accuracy of the content published in our Journal. IJAPR cannot accept any responsibility or liability for the articles content which are published. The views expressed in articles by our contributing authors are not necessarily those of IJAPR editor or editorial board members. 